\title{
HUBUNGAN KONDISI FISIK RUMAH DENGAN KEJADIAN PENYAKIT INFEKSI SALURAN PERNAFASAN AKUT (ISPA) DI WILAYAH KERJA PUSKESMAS KADUR KABUPATEN PAMEKASAN TAHUN 2017
}

Yeni Rohmatul Istihoroh, Umi Rahayu, Pratiwi Hermiyanti

\begin{abstract}
ABSTRAK
Penyakit ISPA menempati peringkat pertama dengan jumlah kasus 284 menurut data dari Puskesmas Kadur pada tahun 2016. Hasil dari survey pendahuluan di 70 rumah pasien penyakit ISPA yaitu $28 \%$ rumah yang lantai rumahnya belum memenuhi persyaratan rumah sehat, dan $78 \%$ rumah yang jarang membuka jendela sehingga tidak ada cahaya matahari masuk ke dalam rumah, dan masih ada $57 \%$ rumah yang pencahayaannya belum memenuhi persyaratan. Penelitian ini bertujuan untuk mengetahui hubungan antara ventilasi, pencahayaan alami, lantai rumah, suhu udara, dan kelembaban udara dengan kejadian penyakit ISPA.

Jenis penelitian ini adalah penelitian analitik dengan pendekatan case control. Populasi di penelitian ini adalah semua rumah penduduk yang terdapat pasien penyakit ISPA yang ada di wilayah kerja Puskesmas Kadur Kabupaten Pamekasan dengan sampel 72 rumah penduduk diambil dengan metode simple random sampling. Analisis data dengan metode chi square untuk mengetahui hubungan variabel bebas dengan variabel terkait. Dan dilanjutkan ke analisis koefisien kontingensi untuk mengetahui besarnya keeratan hubungan kondisi fisik rumah dengan kejadian penyakit ISPA.

Hasil penelitian menunjukan bahwa ada hubungan yang lemah antara intensitas pencahayaan ( $p=0.012, C=0.12$ ) dengan kejadian penyakit ISPA, sedangkan luas ventilasi, suhu udara, dan kelembaban udara tidak ada hubungan dengan kejadian penyakit ISPA.

Kesimpulan dari penelitian ini yaitu ada hubungan antara intensitas pencahayaan dengan kejadian penyakit ISPA dan tidak ada hubungan antara luas ventilasi, lantai rumah, suhu udara, dan kelembaban udara dengan kejadian penyakit ISPA. Sedangkan saran bagi petugas kesehatan yaitu dapat melakukan pencegahan terhadap penyakit ISPA, bagi masyarakat yaitu dapat meningkatkan dan melakukan upaya penyehatan rumah untuk menekan terjadinya penyakit ISPA, dan bagi peneliti lain yaitu dapat melakukan penelitian dengan variabel yang berbeda.

Kata kunci : kondisi fisik rumah, ISPA
\end{abstract}

\section{PENDAHULUAN}

Rumah adalah salah satu dari tiga kebutuhan utama manusia yaitu sandang, pangan, dan papan yang harus terpenuhi, dan harus memenuhi persyaratan kesehatan agar tidak berpengaruh terhadap kesehatan. Terutama perumahan di pedesaan pada umumnya masih berkaitan erat dengan budaya atau tradisi setempat yang biasanya belum memenuhi kondisi kesehatan lingkungan (Kasjono, 2011:11).

Persyaratan kesehatan perumahan menurut Kepmenkes RI nomor 829/Menkes/SK/VII/1999 tentang persyaratan kesehatan perumahan menjelaskan bahwa rumah pada dasarnya merupakan tempat hunian yang sangat penting bagi kehidupan setiap orang. Rumah sehat adalah rumah dengan kondisi fisik, kimia, biologi di dalam rumah dan perumahan sehingga memungkinkan penghuni atau masyarakat memperoleh derajat kesehatan yang optimal. Menurut Undang-Undang RI no.4 tahun 1992 tentang perumahan dan pemukiman, persyaratan kesehatan bangunan meliputi persyaratan sistem penghawaan, pencahayaan, sanitasi, dan penggunaan bahan bangunan. Rumah yang belum memenuhi persyaratan kesehatan akan menimbulkan berbagai risiko terhadap anggota keluarga, terutama berbagai penyakit yang salah satunya adalah infeksi saluran pernafasan atas atau yang biasa disebut ISPA.

Infeksi Saluran Pernafasan Akut (ISPA) sebagai penyakit saluran 
pernafasan akut yang disebabkan oleh agen infeksius yang ditularkan dari manusia ke manusia. Gejala biasanya dalam kurun waktu beberapa jam sampai beberapa hari meliputi demam, batuk, nyeri tenggorokan, pilek, sesak nafas, mengi atau kesulitan bernafas. (WHO, 2007) ISPA adalah infeksi saluran pernapasan akut yang meliputi tiga unsur yakni infeksi, saluran pernapasan dan akut. (Depkes RI, 2007)

Penyakit ISPA menjadi salah satu masalah kesehatan masyarakat karena tingginya angka kematian terutama pada bayi dan balita. Dari seluruh kematian balita, proporsi kematian yang disebabkan oleh ISPA mencakup 20$30 \%$. Setiap anak diperkirakan mengalami 3-6 kali episode ISPA tiap tahun dan $40-60 \%$ dari kunjungan puskesmas adalah ISPA (Depkes RI, 2002). ISPA pada umumnya terjadi lebih parah pada bayi dan anak-anak daripada orang dewasa. Penyakit ini biasanya sembuh dalam 4 sampai 10 hari tanpa komplikasi dan kadangkadang demam berulang. (Hartono, R. 2012)

ISPA merupakan penyakit yang paling banyak diderita oleh anak. Prevalensi ISPA bagian bawah (pneumonia) lebih tinggi pada kelompok umur yang lebih muda. Pneumonia menurut Depkes RI (2009) adalah infeksi akut yang mengenai jaringan paru-paru dan mempunyai gejala batuk dan sesak nafas. Anak umur $<2$ tahun merupakan faktor resiko terjadinya pneumonia karena anak di bawah umur 2 tahun imunitasnya belum sempurna dan saluran pernafasan relatif sempit. Hasil Survei Demografi dan Kesehatan Indonesia (SDKI) tahun 1991 menunjukkan prevalensi pneumonia tertinggi pada kelompok umur 12-23 bulan (Yuliastuti dkk, 1992 dalam Naria, 2008).

Di Kabupaten Pamekasan terdapat 13 Kecamatan dan 20 Puskesmas yang salah satunya adalah Puskesmas Kadur yang memiliki luas wilayah $52,43 \mathrm{~km} 2$ dengan jumlah 10 Desa. Sesuai dengan data yang diperoleh dari Puskesmas Kadur selama satu tahun terakhir penyakit ISPA menduduki urutan pertama dengan jumlah kasus 284 dari 1420 kasus.

Hasil penelitian di wilayah kerja Puskesmas Lubuk Buaya Kota Padang, menyebutkan bahwa hasil pengukuran ventilasi, pencahayaan alami, kepadatan hunian, dan kebiasaan merokok mempunyai hubungan dengan kejadian penyakit ISPA. Hasil penelitian menunjukkan ada hubungan yang lemah antara ventilasi $(p=0.000$, $\mathrm{Cc}=0.359)$, pencahayaan alami $(p=0.001, C c=0.311)$, kepadatan hunian $(p=0.000, C c=0.381)$, dan kebiasaan merokok di dalam rumah $(p=0.002$, $\mathrm{C} C=0.302)$ dengan kejadian ISPA pada balita, sedangkan kelembaban rumah tidak ada hubungan dengan kejadian ISPA pada balita. (Suryani. 2013). Dan dari hasil penelitian di wilayah kerja Puskesmas IV Denpasar Selatan, menyebutkan bahwa terdapat hubungan yang siginifikan antara faktor-faktor sanitasi rumah dengan kejadian penyakit ISPA antara lain jumlah ventilasi yang memenuhi syarat 53 rumah, dan yang tidak memenuhi syarat 39 rumah. Jumlah kelembaban udara yang memenuhi syarat 43 rumah dan yang tidak memenuhi syarat 49 rumah. Jumlah suhu udara yang memenuhi syarat 41 rumah dan yang tidak memenuhi syarat 51 rumah. Jumlah pencahayaan yang memenuhi syarat 39 rumah dan yang tidak memenuhi syarat 53 rumah. (Dewi. 2014)

Survey pendahuluan dilakukan pada 70 pasien penyakit ISPA yang terdapat di wilayah kerja Puskesmas Kadur. Kondisi rumah pasien yang ditemui pada saat survey pendahuluan diduga dapat menyebabkan terjadinya penularan penyakit ISPA karena masih terdapat $57 \%$ rumah dengan kurangnya intensitas cahaya khususnya cahaya matahari yang masuk ke dalam rumah dan masih ada $28 \%$ rumah pasien yang lantainya masih belum memenuhi persyaratan sehingga menyebabkan batuk terutama bagi yang alergi terhadap debu dan masih ada $78 \%$ rumah yang jarang membuka jendela rumah sehingga membuat rumah menjadi lembab dan bakteri mudah berkembang biak. Kondisi rumah yang 
seperti ini memungkinkan terjadinya penularan penyakit ISPA di dalam rumah.

\section{METODE PENELITIAN}

Jenis penelitian ini adalah analitik dengan pendekatan case control yang bertujuan untuk mengetahui ada atau terjadinya faktor risiko penyakit ISPA pada waktu yang lalu.

Penelitian dilakukan di wilayah kerja Puskesmas Kadur Kabupaten Pamekasan karena berdasarkan data dasar Puskesmas Kadur tahun 2016 penyakit ISPA menduduki peringkat pertama dari hasil pencatatan 15 penyakit tertinggi. Penelitian dilakukan antara bulan januari sampai bulan juni 2017.

Semua rumah yang terdapat pasien ISPA di wilayah kerja Puskesmas Kadur Kabupaten Pamekasan tahun 2016 yaitu sebesar 260 rumah yang tersebar di 10 Kelurahan. Sampel yang dipakai adalah
72 rumah yang terdapat pasien ISPA di wilayah kerja Puskesmas Kadur Kabupaten Pamekasan.

Teknik pengambilan sampel yaitu menggunakan teknik simple random sampling. Yaitu mengambil secara acak sampel dan kontrol dengan menggunakan sistem undian. Sampel dan kontrol dalam penelitian ini adalah 72 rumah sampel dan 72 rumah kontrol. Kriteria rumah kontrol yaitu rumah di sekitar pasien ISPA dan rumah yang tidak terdapat pasien penyakit ISPA.

Analisis data dalam penelitian ini yaitu menggunakan metode chi square untuk mengetahui hubungan antara variabel independen (bebas) dengan variabel dependen (terikat). Dan dilanjutkan ke analisis koefisien kontingensi untuk mengetahui besarnya keeratan hubungan variabel independen dengan variabel dependen.

\section{HASIL PENELITIAN}

\section{HASIL PENILAIAN KONDISI FISIK RUMAH DI WILAYAH KERJA PUSKSMAS KADUR TAHUN 2017}

\begin{tabular}{|c|c|c|c|c|c|c|c|c|c|}
\hline \multirow{4}{*}{ NO } & \multirow{4}{*}{ omponen nam } & \multicolumn{8}{|c|}{ Hasil penilaian } \\
\hline & & \multicolumn{4}{|c|}{ Kasus } & \multicolumn{4}{|c|}{ Kontrol } \\
\hline & & \multicolumn{2}{|c|}{ MS } & \multicolumn{2}{|c|}{ TMS } & \multicolumn{2}{|c|}{ MS } & \multicolumn{2}{|c|}{ TMS } \\
\hline & & $\mathrm{n}$ & $\%$ & $\mathrm{n}$ & $\%$ & $\mathrm{n}$ & $\%$ & $\mathrm{n}$ & $\%$ \\
\hline 1 & Luas & 46 & $64 \%$ & 26 & $36 \%$ & 46 & $64 \%$ & 26 & $36 \%$ \\
\hline 2 & & 29 & $40 \%$ & 43 & $60 \%$ & 44 & $61 \%$ & 28 & $39 \%$ \\
\hline 3 & $S$ & 3 & & & 5 & 34 & $47 \%$ & 38 & $53 \%$ \\
\hline 4 & Kelembaban udara & 70 & $97 \%$ & 2 & $3 \%$ & 69 & $96 \%$ & 3 & $4 \%$ \\
\hline \multicolumn{4}{|c|}{$\begin{array}{l}\text { Berdasarkan tabel } 1 \text { diatas diketahui } \\
\text { bahwa pada luas ventilasi terdapat } 46 \\
\text { rumah kasus yang memenuhi syarat, } 26 \\
\text { rumah kasus tidak memenuhi syarat, } 46 \\
\text { rumah kontrol memenuhi syarat, dan } 26 \\
\text { rumah kontrol tidak memenuhi syarat. } \\
\text { Pada intensitas pencahayaan terdapat } \\
29 \text { rumah kasus memenuhi syarat, } 43 \\
\text { rumah kasus tidak memenuhi syarat, } 44 \\
\text { rumah kontrol memenuhi syarat, dan } 28 \\
\text { rumah kontrol tidak memenuhi syarat. }\end{array}$} & \multicolumn{6}{|c|}{$\begin{array}{l}\text { Pada suhu udara terdapat } 35 \text { rumah } \\
\text { kasus memenuhi syarat, } 37 \text { rumah } \\
\text { kasus tidak memenuhi syarat, } 34 \text { rumah } \\
\text { kontrol memenuhi syarat, dan } 38 \text { rumah } \\
\text { kontrol tidak memenuhi syarat. Pada } \\
\text { kelembaban udara terdapat } 70 \text { rumah } \\
\text { kasus yang memenuhi syarat, } 2 \text { rumah } \\
\text { kasus yang tidak memenuhi syarat, } 69 \\
\text { rumah kontrol yang memenuhi syarat, } \\
\text { dan } 3 \text { rumah kontrol yang tidak } \\
\text { memenuhi syarat. }\end{array}$} \\
\hline
\end{tabular}


Tabel 2

HASIL OBSERVASI KONDISI FISIK RUMAH DI WILAYAH KERJA PUSKESMAS KADUR TAHUN 2017

\begin{tabular}{|c|c|c|c|c|c|c|c|}
\hline \multirow{3}{*}{ NO } & \multirow{3}{*}{ Observasi } & \multicolumn{6}{|c|}{ Hasil observasi } \\
\hline & & \multicolumn{2}{|c|}{ Baik } & \multicolumn{2}{|c|}{ Cukup } & \multicolumn{2}{|c|}{ Kurang } \\
\hline & & $\mathrm{n}$ & $\%$ & $\mathrm{n}$ & $\%$ & $\mathrm{n}$ & $\%$ \\
\hline 1 & Ventilasi & 55 & $38 \%$ & 48 & $33 \%$ & & $28 \%$ \\
\hline 2 & Jendela & 42 & & 46 & $\%$ & & $9 \%$ \\
\hline 3 & Cerobong asap & 38 & & 40 & 28 & & $6 \%$ \\
\hline 4 & Pencaha & 36 & & 40 & $28 \%$ & 68 & $47 \%$ \\
\hline 5 & Lantai & 44 & & 55 & $38 \%$ & 45 & $31 \%$ \\
\hline \multicolumn{4}{|c|}{$\begin{array}{l}\text { Berdasarkan tabel } 2 \text { diatas diketahui } \\
\text { bahwa pada observasi ventilasi terdapat } \\
55 \text { rumah dengan kategori baik, } 48 \\
\text { rumah dengan kategori cukup, dan } 41 \\
\text { rumah dengan kategori kurang. Pada } \\
\text { observasi jendela terdapat } 42 \text { rumah } \\
\text { dengan kategori baik, } 46 \text { rumah dengan } \\
\text { kategori cukup, dan } 56 \text { rumah dengan } \\
\text { kategori kurang. Pada observasi }\end{array}$} & \multicolumn{4}{|c|}{$\begin{array}{l}\text { dengan kategori baik, } 40 \text { rumah dengan } \\
\text { kategori cukup, dan } 66 \text { rumah dengan } \\
\text { kategori kurang. Pada observas } \\
\text { pencahayaan terdapat } 36 \text { rumah dengan } \\
\text { kategori baik, } 40 \text { rumah dengan kategor } \\
\text { cukup, dan } 68 \text { rumah dengan kategor } \\
\text { kurang. Pada observasi lantai terdapat } \\
44 \text { rumah dengan kategori baik, } 55 \\
\text { rumah dengan kategori cukup, dan } 45 \\
\text { rumah dengan kategori kurang. }\end{array}$} \\
\hline
\end{tabular}

\section{Tabel 3}

ANALISIS HUBUNGAN KONDISI FISIK RUMAH DENGAN KEJADIAN PENYAKIT ISPA DI WILAYAH KERJA PUSKESMAS KADUR TAHUN

2017

\begin{tabular}{clccc}
\hline NO & \multicolumn{1}{c}{ Variabel } & Nilai $\mathbf{p}$ & $\mathbf{a}$ & Keterangan \\
\hline $\mathbf{1}$ & Luas ventilasi & 1 & 0.05 & Tidak ada hubungan \\
\hline $\mathbf{2}$ & $\begin{array}{l}\text { Intensitas } \\
\text { pencahayaan }\end{array}$ & 0.012 & 0.05 & Ada hubungan \\
$\mathbf{3}$ & $\begin{array}{l}\text { Lantai rumah } \\
\mathbf{4}\end{array}$ & 0,795 & 0,05 & Tidak ada hubungan \\
\hline $\mathbf{5}$ & Kelembara & 0.868 & 0.05 & Tidak ada hubungan \\
\hline
\end{tabular}

Berdasarkan tabel 3 diatas jika a $<$ nilai udara, dan kelembaban udara tidak p maka ada hubungan atau Ho diterima. memiliki hubungan dengan kejadian Pada tabel tersebut menunjukan bahwa penyakit ISPA.

variabel intensitas pencahayaan memiliki hubungan dengan kejadian penyakit ISPA, sedangkan luas ventilasi, suhu

Ket $: p=$ nilai chi square

$a=$ taraf kepercayaan

Tabel 4

ANALISIS KEERATAN HUBUNGAN KONDISI FISIK RUMAH DENGAN KEJADIAN PENYAKIT ISPA DI WILAYAH KERJA PUSKESMAS KADUR TAHUN 2017

\begin{tabular}{ccc}
\hline Variabel & C & Keterangan \\
\hline Intensitas pencahayaan & 0.12 & Korelasi sangat lemah \\
\hline Berdasarkan tabel 4 diatas & Intensitas pencahayaan mempunyai korelasi sangat lemah
\end{tabular} dengan kejadian penyakit ISPA.

Ket : $\mathrm{C}=$ nilai koefisien kontingensi 


\section{PEMBAHASAN}

\section{A. LUAS VENTILASI}

Hasil analisis statistik melalui chi square didapat hasil bahwa tidak ada hubungan antara luas ventilasi dengan kejadian penyakit ISPA di wilayah kerja Puskesmas Kadur kabupaten pamekasan. Nilai yang diperoleh $\mathrm{p}=1>\mathrm{a}=0,05$ yang berarti nilai chi square lebih besar dari nilai taraf kepercayaan yang artinya tidak ada hubungan antara luas ventilasi dengan kejadian penyakit ISPA.

Hal ini dikarenakan pada penelitian di rumah pasien penyakit ISPA sebesar 46 rumah luas ventilasinya telah memenuhi persyaratan yaitu luas ventilasi lebih dari sama dengan $10 \%$ dari luas lantai begitu pula pada rumah kontrol sebesar 46 rumah telah memenuhi persyaratan rumah sehat.

Ventilasi berfungsi untuk proses penyediaan udara segar ke dalam dan pengeluaran udara kotor dari suatu ruangan tertutup secara alamiah maupun mekanis. Ventilasi yang baik menyebabkan udara segar dapat dengan mudah masuk ke dalam rumah. Ventilasi yang kurang baik dapat membahayakan kesehatan khususnya saluran pernafasan. (Nindya, 2005).

Kualitas udara di dalam rumah dipengaruhi oleh salah satunya adalah ventilasi. Luas ventilasi alamiah yang permanen minimal $10 \%$ dari luas lantai, memberikan udara segar dari luar, suhu optimum $22-240 \mathrm{C}$ dan kelembaban $60 \%$. Kurangnya ventilasi akan menyebakan kurangnya $\mathrm{O} 2$ di dalam rumah dan kadar $\mathrm{CO} 2$ yang bersifat racun meningkat. (Kusnoputranto, 2000).

Fungsi utama ventilasi adalah menjaga agar aliran udara di dalam rumah tersebut tetap segar, sehingga terjadi keseimbangan $\mathrm{O} 2$. Kurangnya ventilasi dapat menyebabkan kurangnya $\mathrm{O} 2$ dan meningkatnya kadar $\mathrm{CO} 2$ yang bersifat racun. Ventilasi juga berhubungan dengan kelembaban udara dalam rumah yang merupakan media yang baik untuk bakteri-bakteri penyebab penyakit, bakteri yang berada di udara mudah mengalir keluar dengan adanya ventilasi yang memenuhi syarat kesehatan. (Notoatmodjo, 2003).

B. INTENSITAS PENCAHAYAAN

Hasil analisis statistik melalui chi square didapat hasil bahwa ada hubungan antara intensitas pencahayaan dengan kejadian penyakit ISPA di wilayah kerja Puskesmas Kadur Kabupaten Pamekasan. Nilai yang diperoleh $\mathrm{p}=$ $0,01<a=0,05$ yang berarti nilai chi square lebih kecil dari nilai taraf kepercayaan yang artinya ada hubungan antara intensitas pencahayaan dengan kejadian penyakit ISPA. Penelitian ini sejalan dengan penelitian yang dilakukan oleh Dewi (2014) yang menyatakan bahwa ada hubungan yang signifikan antara pencahayaan dengan kejadian penyakit ISPA.

Hasil pengukuran intensitas pencahayaan dari 72 rumah pasien ISPA yang diteliti hanya 29 rumah yang intensitas pencahayaannya memenuhi persyaratan rumah sehat yaitu lebih dari sama dengan 60 lux. Sedangkan pada 72 rumah kontrol yang diteliti terdapat 44 rumah yang intensitas pencahayaannya memenuhi persyaratan rumah sehat.

Kualitas udara juga dipengaruhi oleh pencahayaan. Rumah yang sehat memerlukan pencahayaan sesuai peruntukan ruang. Kurangnya pencahayaan yang masuk ke dalam rumah, terutama cahaya matahari dapat menjadi media atau tempat yang baik untuk hidup dan berkembang biaknya mikroorganisme. Sebaliknya cahaya yang berlebihan akan mengakibatkan silau dan akhirnya dapat merusak mata. (Notoatmodjo, 2003)

Pencahayaan yang berasal dari sinar matahari dapat membunuh bakteri pathogen dalam rumah, 
misalnya bakteri TBC. Pencahayaan alam atau buatan langsung maupun tidak langsung dapat menerangi seluruh ruangan dengan integritas penerangan minimal 60 lux dan tidak menyilaukan mata. (Kemenkes RI, 1999)

\section{LANTAI RUMAH}

Hasil analisis statistik melalui chi square didapat hasil bahwa ada hubungan antara intensitas pencahayaan dengan kejadian penyakit ISPA di wilayah kerja Puskesmas Kadur Kabupaten Pamekasan. Nilai yang diperoleh $\mathrm{p}=$ $0,7<a=0,05$ yang berarti nilai chi square lebih besar dari nilai taraf kepercayaan yang artinya tidak ada hubungan antara lantai rumah dengan kejadian penyakit ISPA. Penelitian ini sesuai dengan penelitian yang dilakukan oleh Mudehir (2002) yang menyatakan bahwa ada perbedaan yang signifikan presentase anak balita terkena ISPA, anak balita yang tinggal di rumah dengan lantai tidak baik memiliki risiko terkena ISPA 3,1 kali lebih besar dibandingkan dengan anak balita yang tinggal di rumah yang berlantai baik.

Hasil observasi pada penelitian di rumah pasien penyakit ISPA didapat bahwa 44 rumah mendapat hasil baik, 55 rumah mendapat hasil cukup, dan 45 rumah mendapat hasil kurang. Hal ini dikarenakan kondisi lantai di rumah pasien dan kontrol penyakit ISPA masih ada yang lantainya terbuat dari tanah dan tidak memenuhi persyaratan.

Jenis lantai yang memenuhi syarat kesehatan menurut Kemenkes (2011) adalah harus kedap air dan mudah dibersihkan. Lantai rumah yang tidak kedap air dan sulit dibersihkan akan menjadi tempat perkembangan dan pertumbuhan mikroorganisme di dalam rumah. Dikatakan rumah sehat apabila jenis lantai terbuat dari marmer, keramik, teraso, ubin, tegel, plester semen, pasangan bata, kayu, papan, bamboo. Rumah yang mempunyai jenis lantai tanah merupakan salah satu indicator rumah tidak sehat dan jenis lantai tanah lebi banyak ditemukan di daerah pedesaan dibandingkan dengan perkotaan.

\section{SUHU UDARA}

Hasil analisis statistik melalui chi square didapat hasil bahwa tidak ada hubungan antara suhu udara dengan kejadian penyakit ISPA di wilayah kerja Puskesmas Kadur Kabupaten Pamekasan. Nilai yang diperoleh $p=0,8>a=0,05$ yang berarti nilai chi square lebih besar dari nilai taraf kepercayaan yang artinya tidak ada hubungan antara suhu udara dengan kejadian penyakit ISPA. Penelitian ini sesuai dengan penelitian yang dilakukan oleh A.A Anom (2006) yang menunjukan bahwa tidak ada hubungan yang bermakna antara suhu dan kejadian penyakit ISPA.

Pada pengukuran suhu udara di 72 rumah pasien ISPA terdapat 35 rumah yang suhu udaranya memenuhi persyaratan rumah sehat yaitu 180 C - 30o C. Sedangkan pada rumah kontrol terdapat 34 rumah yang suhu udaranya memenuhi persyaratan rumah sehat.

Suhu ruangan harus dijaga yaitu berkisar antara $18-200 \mathrm{C}$. suhu ruang sangat dipengaruhi oleh suhu udara luar, pergerakan udara, kelembaban udara, dan suhu benda-benda yang ada di sekitarnya. Perubahan suhu udara dalam rumah dipengaruhi oleh beberapa factor antara lain penggunaan bahan bakar biomassa, ventilasi yang tidak memenuhi syarat, kepadatan hunian, bahan dan sruktur bangunan, kondisi geografis dan kondisi topografis. (Kemenkes RI, 2011)

\section{E. KELEMBABAN UDARA}

Hasil analisis statistik melalui chi square didapat hasil bahwa tidak ada hubungan antara kelembaban udara dengan kejadian penyakit ISPA di wilayah kerja Puskesmas 
Kadur Kabupaten Pamekasan. Nilai yang diperoleh $p=0,6>a=0,05$ yang berarti nilai chi square lebih besar dari nilai taraf kepercayaan yang artinya tidak ada hubungan antara kelembaban udara dengan kejadian penyakit ISPA. Penelitian ini sesuai dengan penelitian yang dilakukan oleh Suryani (2013) bahwa tidak terdapat hubungan antara kelembaban udara dengan kejadian penyakit ISPA.

Hal ini dikarenakan pada pengukuran kelembaban udara yang dilakukan pada 72 rumah pasien ISPA didapati bahwa 70 rumah yang kelembaban udaranya memenuhi persyaratan rumah sehat yaitu antara $40 \%-70 \%$. Sedangkan hasil pengukuran pada 72 rumah kontrol didapati 69 rumah yang hasil pengkuran kelembaban udaranya memenuhi persyaratan rumah sehat.

Kelembaban yang berlebihan mempengaruhi kualitas udara dalam rumah. Kelembaban yang terlalu tinggi maupun rendah dapat menyebabkan suburnya pertumbuhan mikroorganisme. Kelembaban dipengaruhi oleh konstruksi rumah yang tidak memenuhi syarat misalnya atap yang bocor, lantai dan dinding rumah yang tidak kedap air, serta kurangnya pencahayaan baik buatan maupun alami. (Kemenkes, 2011).

\section{KESIMPULAN}

Kesimpulan yang dapat diambil dari hasil penelitian ini yaitu sebagai berikut :

1. Rata-rata luas ventilasi pada kasus yang memenuhi syarat sebanyak $64 \%$ dan yang tidak memenuhi syarat sebanyak $36 \%$, sedangkan pada kontrol yang memenuhi syarat sebanyak $64 \%$ dan yang tidak memenuhi syarat sebanyak $36 \%$.

2. Rata-rata intensitas pencahayaan pada kasus yang memenuhi syarat sebanyak
$40 \%$ dan yang tidak memenuhi syarat sebanyak $60 \%$, sedangkan pada kontrol yang memenuhi syarat sebanyak $61 \%$ dan yang tidak memenuhi syarat sebanyak $39 \%$.

3. Hasil observasi kondisi lantai menyatakan bahwa $31 \%$ keadaan lantai rumah baik, 38\% keadaan lantai rumah cukup, dan $31 \%$ keadaan lantai rumah kurang.

4. Rata-rata suhu udara pada kasus yang memenuhi syarat sebanyak $49 \%$ dan yang tidak memenuhi syarat sebanyak $51 \%$, sedangkan pada kontrol yang memenuhi syarat sebanyak $47 \%$ dan yang tidak memenuhi syarat sebanyak $53 \%$. Rata-rata kelembaban udara pada kasus yang memenuhi syarat sebanyak $97 \%$ dan yang tidak memenuhi syarat sebanyak 3\%, sedangkan pada kontrol yang memenuhi syarat sebanyak $96 \%$ dan yang tidak memenuhi syarat sebanyak $4 \%$.

5. Tidak ada hubungan antara luas ventilasi dengan kejadian penyakit ISPA di wilayah kerja Puskesmas Kadur tahun 2017.

6. Ada hubungan antara intensitas pencahayaan dengan kejadian penyakit ISPA di wilayah kerja Puskesmas Kadur tahun 2017

7. Tidak ada hubungan antara lantai rumah dengan kejadian penyakit ISPA di wilayah kerja Puskesmas Kadur tahun 2017

8. Tidak ada hubungan antara suhu udara dengan kejadian penyakit ISPA di wilayah kerja Puskesmas Kadur tahun 2017

9. Tidak ada hubungan antara kelembaban udara dengan kejadian penyakit ISPA di wilayah kerja Puskesmas Kadur tahun 2017

\section{SARAN}

1. Bagi petugas

kesehatan/puskesmas

Dapat melakukan pencegahan penyakit ISPA melalui : 
a. Percontohan rumah sehat

b. Penyuluhan tentang rumah sehat

c. Penyuluhan tentang penyakit ISPA dan hubungannya dengan kondisi kesehatan rumah

2. Bagi masyarakat

a. Masyarakat dapat meningkatkan kualitas rumah dengan memenuhi variabel rumah sehat seperti lebih sering membuka jendela pada saat pagi hari agar cahaya matahari bisa masuk ke dalam rumah.

b. Masyarakat yang rumahnya tidak terjangkau oleh cahaya matahari dapat melakukan gentengisasi, sering menjemur peralatan tidur seperti kasur dan bantal.

c. Masyarakat melakukan upaya penyehatan rumah untuk menekan terjadinya penyakit ISPA seperti menyapu lantai yang kotor dan berdebu.

3. Bagi peneliti lain

Peneliti lain dapat melakukan penelitian dengan variabel yang berbeda seperti jenis dinding, luas atap, dll.

\section{DAFTAR PUSTAKA}

Depkes RI. (2009). Pedoman program pemberantasan penyakit infeksi saluran pernafasan akut untuk penanggulangan premonia pada balita. Jakarta : Departemen Kesehatan RI.

Dewi, Putu S, Darmadi, I.G.W, dan Marwati, R.M. 2014. Hubungan faktor-faktor sanitasi rumah dengan kejadian Infeksi Saluran Pernafasan Akut di wilayah kerja Puskesmas IV Denpasar Selatan tahun 2014. Jurnal Kesehatan Lingkungan volume 4 no 2: $175-180$.

Hartono, R dan R.H. Dwi, 2012. ISPA: Gangguan Pernafasan pada Anak. Yogyakarta, Nuha Medika : 27-30.
Kasdjono, Heru Subaris, 2011. Penyehatan Pemukiman. Yogyakarta, Gosyen Publishing : 1-23.

Kementerian Kesehatan RI. 2011. Peraturan menteri kesehatan RI No. 1077/Menkes/PER/V/2011 tentang pedoman penyehatan udara dalam ruang rumah. Jakarta : Kemenkes RI.

Keputusan Menteri Kesehatan No. 829/Menkes/SK/VII/1999 tentang persyaratan kesehatan perumahan. Jakarta : Kepmenkes RI.

Kusnopuntoro, H dan Susana, D. (2000). Kesehatan Lingkungan. Depok, Fakultas Kesehatan Masyarakat Universitas Indonesia.

Mudehir, M. 2002. Hubungan faktorfaktor lingkungan rumah dengan kejadian penyakit ISPA pada anak balita di Kecamatan Jambi Selatan tahun 2002. Depok, Fakultas Kesehatan Masyarakat Universitas Indonesia.

Nindya, T.S. 2005. Hubungan sanitasi rumah dengan kejadian ISPA. FKM Universitas Airlangga.

Notoatmodjo, Soekidjo. 2003. Pendidikan dan perilaku kesehatan. Jakarta, Rineka Cipta.

Notoatmodjo, Soekidjo, 2007. Promosi Kesehatan dan IImu Perilaku. Jakarta, Rineka Cipta : 55-59.

Suryani, Irma, Edison, dan Nazar, Julizar. 2013. Hubungan lingkungan fisik dan tindakan penduduk dengan kejadian ISPA pada balita di wilayah kerja Puskesmas Lubuk Buaya. Jurnal kesehatan andalas. Volume 4(1): 157 $-167$.

Undang - Undang RI Nomor 4 tahun 1992 tentang perumahan dan pemukiman. Jakarta : UUD RI.

World Health Organization (WHO), 2004. Rumah sehat dan persyaratannya

Yuliastuti, dkk, 1992. Gambaran Selintas Pasien ISPA di Poliklinik UPA RSUP Dr. Sardjito Yogyakarta. Yogyakarta : Berita Kedokteran Masyarakat. 